\title{
Chitosan-properties and applications in dentistry
}

\begin{abstract}
Chitosan is a biopolymer that has a large wound management application and biological proprieties, helping the organisms with fast healing, stimulates the cell proliferation including bacteriostatic and fungistatic particularly useful for wound treatment and as a support material to tissue engineering. The possibilities of application of chitosan are so huge and fascinating as well as not quite discovered. Proprieties of chitosan like biocompatibility, anti inflammatory and others could give promising results in periodontal care or wound healing after teeth extractions. The aim of this work is to review possible applications of chitosan in dentistry area.
\end{abstract}

Keywords: chitosan, biomedical, bioengineering materials, biodegrability, selective permeability, polyelectrolyte action, natural polysaccharide
Volume 2 Issue 4 - 2017

\author{
Kmiec M, Pighinelli L, Tedesco MF, Silva MM, \\ Reis $V$ \\ Universidade Luterana do Brasil, Brazil
}

Correspondence: Kmiec M, Universidade Luterana do Brasil, Campus Canoas, Av Farroupilha, n 800 I, Bairro São José, 92425-900, Canoas/RS, Brazil,

Email marzena.kmiec80@gmail.com

Received: February 19,2017 | Published:June 08, 2017

\section{Introduction}

Biomaterials are those non-living materials used in the medical, biomedical and other fields, aiming to interact with the biological system. ${ }^{1}$ Many of these materials, such as chitosan, are used as effective alternatives for the replacement of tissues, including bone tissue, since they do not present risks of disease transmission or immune rejection, as well as unlimited availability and low cost. ${ }^{2}$ Recently, several researches have been carried out aiming at new materials capable of being associated with other substances that promote bone formation, especially biopolymers, in particular chitosan, which presents great potential in the repair of bone defects, in relation to the limitations of other biomaterials. ${ }^{3}$

One of the most important fields of applications of natural compounds it is medicine. Such materials would have some advantages over synthetic ones. Materials derived from the nature, have been shown to yield faster healing with less incompatibility in human beings. The new materials which are used should help to reduce the operation time and improve patient recovery. The development of reconstructive surgery, cardiac surgery, transplantation and dentistry would not have been possible without progress in the field of material science, chemistry and technology polymers for biomedical and bioengineering materials. One of the new and promising biomaterials being used in dentistry is chitosan. ${ }^{4}$

Chitosan and its derivatives have excellent biocompatibility, nontoxicity to human beings, biodegrability, reactivity of the deacetylated amino groups, selective permeability, polyelectrolyte action, antimicrobial activity, ability to form gel, film and sponge, absorptive capacity, anti-inflammatory and wound healing. ${ }^{5}$ One of the most important properties of chitosan is high bioactivity, that makes this material very interesting to develop new biomaterials for application in dentistry area.

The use of biopolymers in the treatment of diseased tissues was started in the area of dentistry. The scientific and technological advances in the area of biomaterials and medical devices have allowed a considerable evolution in this area, in particular, focusing on new biomacromolecules and biocompatible materials for clinical use. ${ }^{6}$

Chitin (Figure 1) is a natural polysaccharide from crustacean shells, insect cuticles, and on fungal cell walls is the second most abundant polymerized carbon found in nature. ${ }^{7}$ The chitosan (Figure 1) is obtained from the alkaline deacetylation of chitin. This copolymer obtained is biodegradable, consisting of D-glucosamine units containing a free amino group. Chitosan can be used in a large number of industrial applications, among which the following stand out: biocompatibility, biodegradability, antibactericidal, emulsifying and chelating properties. ${ }^{8}$ Due to these biological characteristics, several applications have been found for this biomaterial, among them: in agriculture, in the food industry and, recently, in the medical field..$^{9,10}$

The purpose of this study is to investigate the potential of Chitosan, based on promising properties and reliable biological functionalities emphasizing the dental area. Look for new methods and applications due to their excellent biocompatibility.

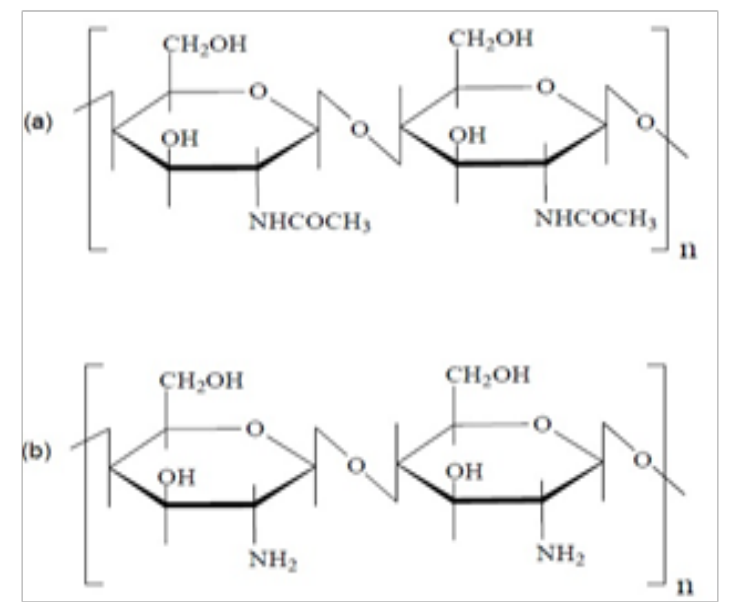

Figure I Schematic representation of the primary structures of (a) chitin and (b) chitosan.

\section{Chitosan}

The discovery of chitosan was in 1859 by Rouget when the chitin was subjected to a treatment with hot potassium hydroxide solution. In the period of 1894, Gilson confirmed the presence of glucosamine in chitin and in the same period was named chitosan 
by Hopper-Seyler. ${ }^{11,12}$ Since then several researches with interests in the applications of chitin and aiming to broaden the knowledge about the structural relations and properties of this polysaccharide and its derivatives. $^{13}$

Chitosan is a straight chain, cationic polysaccharide that occurs naturally or can be obtained by deacetylation of chitin. Even though there is no nomenclature that definitively guarantees a difference between chitin and chitosan, the term chitosan usually represents cationic copolymers consisting of 2-amino-2-deoxy- $\beta$-D-glucose (60-100\%) and 2-acetamino -2-deoxy- $\beta$-D-glucoside $(0-50 \%)$, bound together by $\beta(1 \rightarrow 4)$ bonds. ${ }^{14-17}$ Chitosan is the main derivative of chitin deacetylation in which the mean degree of deacetylation representing the percentage of free NH 2 groups is greater than $60 \% .^{18,19}$

The average degree of acetylation of chitosan is a measure of the average number of 2-acetamide-2-dexosi-D-glucopyranose and 2-amino-2-deoxy-D-glucopyranose units. The relative percentage of these units has a direct influence on the solubility of chitosan and is an important parameter to determine the average degree of acetylation or indirectly the average degree of deacetylation, which in this way represents the concentration of amino groups, besides exerting a great influence on the physical properties, chemical and biological. ${ }^{11}$

The amino groups of chitosan are more reactive with respect to the acetamido groups of chitin. The free electron pair of nitrogen in the amino groups is responsible for the adsorption of metallic cations. The average degree of deacetylation determines the fraction of amino groups that are available for interaction with metals. The protonation of amino groups in acid solutions is responsible for the electrostatic attraction of anions..$^{14}$

Unlike chitin, chitosan is soluble in dilute acid medium forming a cationic polymer that confers special properties differentiated with respect to the vegetal fibers. ${ }^{11}$ Chitosan is soluble in dilute acids, such as acetic acid, formic acid, lactic acid, as well as inorganic acids, after prolonged agitation. However, the solubility is dependent on several parameters, such as the degree of deacetylation, molar mass, concentration of acid and biopolymer and ionic strength. ${ }^{19}$

Chitosan, for the most part, consists of 2-amino-2-deoxy-D-glucose units linked by $\beta-(1-4)$ linkage. In addition to the flexible structure of the polymer chain, chitosan has potentially reactive functional groups: amino (-NH2) groups, several primary and secondary hydroxyl groups at the C-2, C-3 and C-6 positions, respectively, which have strong affinity with water. ${ }^{20}$

Due to its characteristics of biodegradability, biocompatibility, hydrophilicity, antibacterial properties, bioactivity and to be processed in different forms (solutions, blends, sponges, membranes, gels, pastes, tablets, microspheres and micro granules, among others) chitosan is widely used. Also because it comes from natural and renewable resources. ${ }^{17,21-23}$

\section{Relevant properties for dentistry}

Properties of chitosan that are perhaps the most important to dentistry are bioactivity, anti-inflammatory, wound healing, hemostasy and bone repair.

\section{Bioactivity}

To use of chitosan appears to be very promising recent introduction in the design of new materials. Associations between chitosan and calcium-phosphate mineral maintain a high degree of bioactivity, which appears to be favored by the functional and structural versatility of chitosan. ${ }^{24}$

For example, in the field of ceramic materials, which are widely used in dentistry, a common characteristic of bioactive glass-ionomer cements is that of determining the formation of a biologically active layer of carbonate-hydroxyapatite that bonds to the collagen fibers of the tissue with which it interfaces. ${ }^{24}$

In dental material can be many challenges of antibacterial agents. Concentration of the agent must be sufficiently adequate to inhibit or reduce the formation of bio-film but does not exceed the level of cytotoxicity. Effect should not be limited in time and mechanical, chemical and aesthetic properties of material may not deteriorate..$^{25,26}$

Chitosan as a natural carbohydrated biopolymer with a unique structure and properties, may fulfill the criteria described above. Chitin and chitosan have been investigated as antimicrobial agents against a broad range of target microorganisms such as algae, bacteria, yeasts and fungi in vivo and in vitro experiments involving chitosan in various forms (solutions, films and composites). ${ }^{26,27}$ This biopolymer has to be extremely promising in this area since it shows a strong activity in reducing dental plaque as well as proven in vitro antimicrobial activity against various pathogenic oral cavities directly involved in plaque formation and periodontal disease such as Actinobacillus actinomycetemcomitans, Streptococcus mutans and $P$. gingivalis. ${ }^{27}$

Electrostatically negatively charged surface of bacterial cells in the interaction with the positively-charged amino groups, NH3+, may cause damage to the cell wall. This can lead to changes in permeability and barrier properties causing leakage of cell contents. Such antibacterial action has demonstrated by chitosan against oral bacteria. There are many tests for use chitosan as antimicrobial agent in composites, dental materials and oral hygiene products. ${ }^{27}$

According to Kong et al. ${ }^{28}$ there are four main categories of factors that influence the antibacterial action of chitosan:

\section{Microbial factors (microbial species, age of the cell);}

2. Intrinsic factors of the chitosan (positive charge density, molecular weight, hydrophobic and hydrophilic characteristics, chelation capacity);

\section{Physical state factors (soluble and solid state) and}

4. Environmental factors ( $\mathrm{pH}$, ionic forces, temperature, time).

The antimicrobial activity of chitosan for gram-negative and gram-positive bacteria, ranges from 100 up to $100,000 \mathrm{mg} \mathrm{1-1}$ and 100 up to $1,250 \mathrm{mg} 1-1$, respectively. To date there is enough evidence to support that chitosan molecular mass can influence the solubility and its antibacterial activity. $5,29,30$

\section{Wound healing and hemostase}

During invasive dental treatments can occur bleeding disorders and dentists must be ready for it. To get the most effective way to control bleeding and wound healing, the best and popular solution is to use hemostatic agent. ${ }^{31-34}$

They have been carried out the study, which aimed to evaluate the effectiveness of chitosan on wound healing and hemostasis after teeth extraction. For this purpose was used Hemcon Dental Dressing 
(HDD). In US, military is manufactured Hem Con Bandage (HB) forms of freeze dried chitosan. HDD is oral hemostatic wound dressing delivered from HB. Dressing reduces pain and recovery time by creating a physical barrier to protect the wound surface. The results proved that HDD without the need of additional hemostatic measures was effective to stop bleeding after dental extraction. ${ }^{35,36}$

There are several phases of wound healing (Homeostasis \& Coagulation, Inflammation, proliferative \& Migration, Remodeling) and a number of in vitro studies revealed that properties of chitosan are working advantageously in each of them. This can explain that specific cells, which are involved in the process of wound healing are affected by chitosan. ${ }^{37,38}$

Before and after surgery it is important to the efficient operation of the immune system. Immunomodulators act as regulators of the body resistance to various kinds of infections. Chitosan has immunomodulators property and stimulate macrophages to release IL-1 which in turn stimulates fibroblast proliferation and collagen influence the structure. Chitosan in general release acetylglucosaminidase $\mathrm{N}$ like a product of hidrolitic and enzymatic degradation, increase biosintesis of hyaluronic acid and extra cellular components related with scarring formation. After applying chitosan wounds were characterized by an increased number of collagen and osteopontin and a heavy infiltration of polymorphonuclear leucocytes (PMN). The cicatrizing capacity depends upon degree of deacetylation (DD) of chitin and chitosan. Chitosan has higher DD than chitin which results in the appearance of a more active fibroblasts and greater resistance to bursting wounds. ${ }^{26}$

\section{Anti-inflammatory}

The natural defense answer of our body caused by damaging factors of chemical, physical or biological is inflammation. In dentistry we are often faced with certain periodontal diseases that cause this condition. Studies have shown that chitosan and its derivatives are able to influence this process in many different ways. It is associated with the presence of N-acetyl-D-glucosamine, which stimulates inflammatory cells such as macrophages, fibroblasts and PMN neutrophils. ${ }^{26}$ Studies, that have been carried out about effects of chitosan particles pathogens in periodontal and gingival fibroblasts, have brought good results and showed that chitosan may be a good material for the treatment of inflammation in the periodontum. However there is a question mark, whether equally good results will be achieved in tests in vivo. Therefore, further studies are required in this direction. ${ }^{3}$

\section{Bone repair}

There are many serious diseases that cause damage to the bone and which constitute a great challenge. These include for example, tumor resection and osteolysis due to dental and bone lesions or periodentium tissue disorders. By increasing the number of invasive surgical treatments, in fields such as dentistry and orthopedics, it is extremely important improvement and the search for new materials for bone repair techniques. These materials should help in the shortened time treatments, reducing the size of scars and pain after surgery, as well as a faster recovery of the patient. ${ }^{4,39}$

Features such as chitosan biodegrability and biocompatibility enable application of this biomaterial for hard tissue repair process. It works on the principle of temporary scaffolding in a bone substitute, pending resorption of the implant and replacement by natural bone.

The chitosan chemical arrangements have a big influence in the mechanical properties such $\mathrm{H}$-bonds chains and crosslinkings and $\mathrm{NH} 2+$ with negative tissues in the human body, providing good stability and a frame work to start a new bones cells formation and in case of regeneration an early stage of bone healing. ${ }^{37}$

Many researches have been made, confirming that properties of chitosan has incredible impact on bone regeneration and healing. Some studies have shown that chitosan in the form of sponge activates osteoblasts and could increase osteogenesis. ${ }^{31}$ In Klokkevold report chitosan increases the activity of osteoblasts and helps bone formation..$^{32}$ Results of other group of researchers reported that spongy chitosan supports the proliferation of osteoblastic cells. ${ }^{33}$

Regarding the properties of chitosan as a biomaterial for bone repair, research was carried out to see the effects of chitosan on dental socket repair after tooth extraction. After 10 weeks, found very interesting results. The bone density in middle and apical section of the sockets treated was significantly more. Regenerated bone reached up to $98,2 \%$ of normal mandibular bone density. In each patient, the bone density in epical and middle sections was increase $29.3 \%$ and $10,8 \%$ of normal bone density. The results confirm that in chitosanfilled socket bone tissue regeneration will be faster than untreated dental socket. ${ }^{30}$

\section{Chitosan: potential application for dentistry}

Rapid development of civilization and technology involve a number of advantages and also many consequences. More often we are turn to the nature in search for materials and solutions that will be friendly to us and our environment. Chitin and chitosan are one of those products. Properties of chitosan such as biocompatibility, biodegrability, non-toxicity, antibacterial opens many possibilities of application. The main of them are: water and waste treatment, agriculture, food and beverages, paper industry, cosmetics and toiletries, biopharmaceutical and the major one is biomedical area. ${ }^{26,40}$ Table 1 representing different chitosan application in dentistry collected from 56 different articles. ${ }^{39}$

Table I Chitosan application in dentistry area. ${ }^{39}$

\begin{tabular}{|c|c|c|c|}
\hline $\begin{array}{l}\text { Dental } \\
\text { specialties }\end{array}$ & Chitosan applications & Type of research & Reference \\
\hline \multirow[t]{4}{*}{$\begin{array}{l}\text { Preventive } \\
\text { dentistry }\end{array}$} & Component of daily mouth wash & In vivo & 25,41 \\
\hline & Component of toothpaste against dental plaque & In vivo/In vitro & 42 \\
\hline & Component of toothpaste againsterosion/abrasion & In vitro/In vivo & 43,44 \\
\hline & Mucoadhesive cariostatic substance delivery systems & In vivo & 45 \\
\hline $\begin{array}{l}\text { Conservative } \\
\text { dentistry }\end{array}$ & Direct pulp capping & In vitro/In vivo & 46,47 \\
\hline
\end{tabular}


Table continued...

\begin{tabular}{|c|c|c|c|}
\hline $\begin{array}{l}\text { Dental } \\
\text { specialties }\end{array}$ & Chitosan applications & Type of research & Reference \\
\hline & Antibacterial against S. mutans & In vitro & 48 \\
\hline & $\begin{array}{l}\text { Component of toothpaste against erosion/abrasion included demineralised dentine } \\
\text { matrix }\end{array}$ & In vitro & 49 \\
\hline & Indirect pulp capping & In vitro & 50 \\
\hline \multirow[t]{6}{*}{ Endodontics } & Antibacterial against $E$. faecalis using new photo sensitizer & In vitro & $5 I-55$ \\
\hline & $\begin{array}{l}\text { Sustained release of calcium ions from the calcium hydroxide in the root canal } \\
\text { system }\end{array}$ & In vitro & 56,57 \\
\hline & Improving stability of dentin collagen & In vitro & 58 \\
\hline & Removal of smear layer after root canal instrumentation & In vitro & 59 \\
\hline & Inhibition of biofilm by incorporation with zinc-oxide eugenol-based sealer & In vitro & 60 \\
\hline & Ingredient of triple antibiotic intracanal paste against Candida albicans and E. faecalis & In vitro & 62 \\
\hline \multirow[t]{8}{*}{ Oral surgery } & Guided bone regeneration & In vivo/In vitro/In vivo & $63-65$ \\
\hline & Facilitate early bony consolidation in distraction osteogenesis & In vivo & 66 \\
\hline & Bone regeneration at dental implant defects & In vivo & 67,68 \\
\hline & Titanium coating & In vivo & 69 \\
\hline & Hemostasis of oral surgery wounds & In vivo & $36,70,71$ \\
\hline & Bone tissue engineering in oral reconstruction & In vivo & 72 \\
\hline & New bone substitute material & In vitro/In vivo & 73,74 \\
\hline & Repairing TMJ disc-Guided periodontal tissue regeneration & In vivo & 75 \\
\hline \multirow{7}{*}{ Periodontology } & Antioxidant delivery system & In vivo & 78 \\
\hline & Epithelial attachment re growth & In vitro/In vivo & 79,80 \\
\hline & Antibacterial and plaque-reducing action & In vivo & 81 \\
\hline & Treatment of periodontitis & In vivo & 82 \\
\hline & Advanced scaffolds in periodontal tissue engineering & In vitro/In vivo & $83-86$ \\
\hline & Antimicrobial photodynamic therapy against $P$. gingivalis & In vitro & 87 \\
\hline & Periodontal ligament cells delivery system & In vitro & 88 \\
\hline \multirow[t]{4}{*}{$\begin{array}{l}\text { Prosthetic } \\
\text { dentistry }\end{array}$} & Modification of glass ionomer restoratives & In vitro & 89 \\
\hline & Antibacterial activity of composite & In vitro & 90 \\
\hline & Antibacterial activity of dental adhesive & In vitro & 91 \\
\hline & Modification of lithium disilicate glass ceramic cementation procedure & In vitro & 92 \\
\hline Orthodontics & Preventing against demineralization around orthodontic brackets & In vivo & 93 \\
\hline
\end{tabular}

Application of chitosan in dentistry is the subject of research for decades. Thanks to its characteristics and possibility to create a complex for what may be in various forms. Chitosan in the form of gel and hydrogels applies to the treatment of chronic periodontitis and canker sores. Toothpastes, mouthwashes and chewing gums based on chitosan and herbs fullness functions antimicrobial effect on oral bio film and reduction of the number of $S$. mutans in the oral cavity. ${ }^{10,29}$ Chitosan complex and fluoride micro particles increase fluoride absorption and protection cavities. Endodontic cements based on chitosan reduces inflammation and support bone regeneration. ${ }^{26}$

\section{Conclusion}

Chitosan has been studied due to the superior properties of this biopolymer and along of the years comes incentivating new researches at the tissue engineering area. Chitosan offers great opportunities for a bright future, we are focused to bring new possibilities to the chitosanbased products. Chitosan has been a "promising" biomaterial for fifty years, bringing together academic researches and the biomedical 
industries. It is proved that this biopolymer has enough capability to be used as substitute skin, blood anticoagulation, antimicrobial, antiinflammatory, bone healing and regeneration as such an infinity of others fantastic applications. The potential of Chitosan shown in this article focused manly in dentistry area.

\section{Acknowledgements}

None.

\section{Conflict of interest}

The author declares no conflict of interest.

\section{References}

1. Williams KR, Blayney AW. Tissue response of several polymeric materials implanted in the rat middle ear. Biomaterials. 1987;8(4):254-258.

2. Hall EE, Meffert RM, Hermann JS, et al. Comparison of bioactive glass to demineralized freeze-dried bone allograft in the treatment of intrabony defects around implants in the canine mandible. J Periodontol. 1999;70(5):526-535.

3. Park JS, Choi SH, Moon IS, et al. Eight-week histological analysis on the effect of chitosan on surgically created one-wall intrabony defects in beagle dogs. J Clin Periodontol. 2003;30(5):443-453.

4. Ezoddini Ardakani F, Navab Azam A, et al. Effects of chitosan on dental bone repair. Health. 2011;3(4):200-205.

5. Souza Gadelha de Crvalho MM, Montenegro Stamford TC, Pereira dos Santos E, et al. Chitosan as an oral antimicrobial agent. Science against microbial pathogens: communicating current research and technological advances; 2011. p. 542-550

6. Ji QX, Zhong DY, Lu R, et al. In vitro evaluation of the biomedical properties of chitosan and quaternized chitosan for dental applications. Carbohydr Res. 2009;344(11):1297-1302.

7. Malafaya PB, Silva GA, Reis RL. Natural origin polymers as carriers and scaffolds for biomolecules and cell delivery in tissue engineering applications. Adv Drug Deliv Rev. 2007;59(4-5):207-233.

8. Motta de Moura C, Muszinski P, Schmidt C, et al. Quitina e quitosana produzidas a partir de resíduos de camarão e siri: avaliação do processo em escala piloto. Disponivel em. 2014;16(1).

9. Senel S, Ikinci G, Kas S, et al. Chitosan films and hydrogels of chlorhexidine gluconate for oral mucosal delivery. Int J Pharm. 2000;193(2):197203.

10. Singla AK, Chawla M. Chitosan: some pharmaceutical and biological aspects--an update. J Pharm Pharmacol. 2001;53(8):1047-1067.

11. Goosen MFA. Application of Chitin and Chitosan. Switzerland: Technomic publishing AG; 1997.

12. Velasquez CL. Algunos usos del quitosano en sistemas acuosos. Revista Iberoamericana de Polímeros. 2003;4(2):91-109.

13. Campana Filho SP, Britto D, Curti C, et al. Extração, estruturas e propriedades de $\alpha$ - e $\beta$-quitina. Química Nova. 2007;30(3):644-650.

14. Santos JE. Preparação, caracterização e estudos termoanalíticos de bases de shiff biopoliméricas e seus complexos de cobre. 124f. Tese (Doutorado em Ciências - Área Química Analítica) - Departamento de Química. Universidade federal de São Carlos, São Carlos, Brazil: Springer; 2004.

15. Canella KMNC, Garcia RB. Caracterização de quitosana por cromatografia de permeação em gel - influência do método de preparação do solvente. Quimica Nova. 2001;24(1):13-17.
16. Azevedo V, Chaves S, Bezerra D, et al. Quitina e quitosana: aplicações como biomateriais. Revista Eletrônica de Materiais e Processos. 2007;2(3):27-34.

17. Carvalho $\mathrm{T}$. Biomateriais à base de quitosana de camarão e bactérias para remoção de metais traços e petróleo, Universidade Federal do Ceará: Brazil; 2006.

18. Ng JC, Cheung WH, McKay G. Equilibrium studies of the sorption of $\mathrm{Cu}$ (II) Ions onto chitosan. J Colloid Interface Sci. 2002;255(1):64-74.

19. Varma AJ, Deshpande SV, Kennedy JF. Metal complexation by chitosan and its derivatives: A review. Carbohydr Polym. 2004;55(1):77-93.

20. Peter MG. Applications and Environmental aspects of chitin and chitosan. J Macromol Sci Pure \& Appl Chem. 1995;32(4):629-640.

21. Kumar MNVR, Muzzarelli RAA, Muzzarelli C, et al. Chitosan chemistry and pharmaceutical perspectives. Chem Rev. 2004;104(12):6017-6084.

22. Gallstedt M, Hedenqvist MS. Packaging-related mechanical and barrier properties of pulp-fiber-chitosan sheets. Carbohydrate Polymers. 2006;63(1):46-53.

23. Pillai CKS, Paul W, Sharma CP. Chitin and chitosan polymers: chemistry, solubility and fiber formation. Progress in Polymer Science. 2009;34(7):641-678.

24. Mattioli Belmonte M, De Benedittis A, et al. Bioactivity of chitosan in dentistry. Preliminary data on chitosan-based cements. Minerva Stomatol. 1999;48(12):567-576.

25. Mohire NC, Yadav AV. Chitosan based polyherbal toothpaste: As novel oral hygiene product. Indian J Dent Res. 2010;21(3):380-384.

26. Tavaria FK, Costa EM, Pina Vaz I, et al. A quitosana como biomaterial odontológico: estado da arte. Rev Bras Eng Bioméd. 2013;29(1):110 120 .

27. Chitosan-antibacterial use in dental materials. NIOM Nordic Institute of Dental Materials-Newsletter, Norway: Springer; 2105.

28. Kong M, Chen XG, Xing K, et al. Antimicrobial properties of chitosan and mode of action: A state of the art review. Int J Food Microbiol. 2010;144(1):51-63.

29. Chavez de Paz LE, Resin A, Howard KA, et al. Antimicrobial effect of chitosan nanoparticles on Streptococcus mutans biofilms. Appl Environ Microbiol. 2011;77(11):3892-3895.

30. Singh A, Bhambhal A, Saxena V, et al. Chitosan in dentistry. Journal of the Indian association of public health dentistry. 2011;9(18):808-814.

31. Park YJ, Lee YM, Park SN, et al. Palatelet derived growth factor releasing chitosan sponge for periodontal bone regeneration. Biomaterials. 2000;21(2):153-159.

32. Klokkevold PR, Newman MG. Current status of dental implants: A periodontal perspective. Int J Oral Maxillofac Implants. 2000;15(1):56-65.

33. Lee YM, Park YJ, Lee SJ, et al. Tissue engineered bone formation using chitosan/tricalcium phosphate sponges. J Periodontol. 2000;71(3):410 417.

34. Arancibia R, Maturana C, Silva D, et al. Effects of Chitosan particles in periodontal pathogens and gingival fibroblasts. J Dent Res. 2013;92(8):740-745.

35. ElShiha HY, Abdel Monem Tawfik H, Abou Samrah NK, et al. Efficacy of chitosan and absorbable gelatine sponge on hemostasis and wound healing following tooth extraction "A Comparative Study". Egyptian Dental Journal; 2012.

36. Malmquist JP, Clemens SC, Oien HJ, et al. Hemostatic of oral surgery wounds with the HemCon dental dressing. J Oral Maxillo fac Surg. 2008;66(6):1177-1183 
37. Muzzarelli C, Muzzarelli RA. Natural and artificial chitosan-inorganic composites. J Inorg Biochem. 2002;92(2):89-94.

38. Tyler G St Denis, Dai T, Huang YY, et al. Wound-healing properties of chitosan and its use in Wound dressing biopharmaceuticals. Pharmaceutical \& Medicinal Chemistry, USA: Wiley Online Library; 2012.

39. Wieckiewicz M, Boening KW, Grychowska N, Clinical application of chitosan in dental specialities. Mini Rev Med Chem. 2017;17:401-409.

40. Rinaudo M. Chitin and chitosan: Properties and applications. Prog Polym Sci. 2006;31(7):603-632.

41. Sano H, Shibasaki K, Matsukubo T, et al. Effect of chitosan rinsing on reduction of dental plaque formation. Bull Tokyo Dent Coll. 2003;44(1):916.

42. Marsh PD. Dental plaque: biological significance of biofilm and community life-style. J Clin Periodontol. 2005;32(Suppl 6):7-15.

43. Ganss C, von Hinckeldey J, Tolle A, et al. Efficacy of the stannous ion and a biopolymer in toothpastes on enamel erosion/abrasion. $J$ Dent. 2012;40(12):1036-1043.

44. Schlueter N, Klimek J, Ganss C. Randomised in situ study on the efficacy of a chitin/chitosan toothpaste on erosive-abrasive enamel loss. Caries Res. 2013;47(6):574-581.

45. Samprasit W, Kaomongkolgit R, Sukma M, et al. Mucoadhesive electrospun chitosan-based nanofiber mats for dental caries prevention. Carbohydr Polym. 2015;6(117):933-940.

46. Matsunaga T, Yanagiguchi K, Hamada S, et al. Chitosan monomer promotes tissue regeneration on dental pulp wounds. J Biomed Mater Res A. 2006;76(4):711-720.

47. Li F, Liu X, Zhao S, Wu H, et al. Porous chitosan bilayer membrane containing TGF- $\beta 1$ loaded microspheres for pulp capping and reparative dentin formation in a dog model. Dent Mater. 2014;30(2):172-181.

48. Kim JS, Shin DH. Inhibitory effect on Streptococcus mutans and mechanical properties of the chitosan containing composite resin. Restor Dent Endod. 2013;38(1):36-42.

49. Ganss C, Klimek J, Schlueter N. Erosion/abrasion-preventing potentia of $\mathrm{NaF}$ and $\mathrm{F} / \mathrm{Sn}$ /chitosan toothpastes in dentine and impact of the organic matix. Caries Res. 2014;48(2):163-169.

50. Chen Z, Cao S, Wang H, et al. Biomimetic remineralization of demineralized dentine using scaffold of CMC/ACP nanocomplexes in an in vitro tooth model of deep caries. PLoS One. 2015;10(1):e0116553.

51. Shrestha A, Shi Z, Neoh KG, et al. Nanoparticulates for antibiofilm treatment and effect of aging on its antibacterial activity. $J$ Endod. 2010;36(6):1030-1035.

52. Shrestha A, Hamblin MR, Kishen A. Characterization of a conjugate between Rose Bengal and chitosan for targeted antibiofilm and tissue stabilization effects as a potential treatment of infected dentin. Antimicrob Agents Chemother. 2012;56(9):4876-4884.

53. Shrestha A, Hamblin MR, Kishen A. Photoactivated rose Bengal functionalized chitosan nanoparticles produce antibacterial/biofilm activity and stabilize detin-collagen. Nanomedicine. 2014;10(3):491-501.

54. Shrestha A, Kishen A. Antibacterial efficacy of photosensitizer functionalized biopolymeric nanoparticles in the presence of tissue inhibitors in root canal. J Endod. 2014;40(4):566-570.

55. Shrestha A, Cordova M, Kishen A. Photoactivated polycationic bioactive chitosan nanoparticles inactivate bacterial endotoxins. $J$ Endod. 2015;41(5):686-691.

56. Ballal NV, Shavi GV, Kumar R, et al. In vitro sustained release of calcium ions and $\mathrm{pH}$ maintenance from different vehicles containing calcium hydroxide. J Endod. 2010;36(5):862-866.
57. Grover C, Shetty N. Evaluation of calcium ion release and change in $\mathrm{pH}$ on combining calcium hydroxide with different vehicles. Contemp Clin Dent. 2014;5(4):434-439.

58. Shrestha A, Friedman, Kishen A. Photodynamically crosslinkes and chitosan-incorporated dentin collagen. J Dent Res. 2011;90(11):1346-1351.

59. Silva PV, Guedes DF, Nakadi FV, et al. Chitosan: a new solution for removal of smear layes after root canal instrumentation. Int Endod J. 2013;46(4):332-338.

60. DaSilva L, Finer Y, Friedman S, et al. Biofilm formation within the interface of bovine root dentin treated with conjugated chitosan and sealer containing chitosan nanoparticles. J Endod. 2013;39(2):249-253.

61. Shrestha A, Diogenes A, Kishen A. Temporal-controlled release of bovine serum albumin from chitosan nanoparticles: effect on the regulation of alkaline phosphatase activity in steam cells from apical papilla. $J E n-$ dod. 2014;40(9):1349-1354.

62. Shaik J, Garlapati R, Nagesh B, et al. Comparative evaluation of antimicrobial efficacy of triple antibiotic paste and calcium hydroxide using chitosan as carrier against Candida albicans and Enterococcus faecalis: A in vitro study. J Conserv Dent. 2014;17(4):335-339.

63. Shin SY, Park HN, Kim KH, et al. Biological evaluation of chitosan nanofiber membrane for guided bone regeneration. $J$ Periodontal. 2005;76(10):1778-1784.

64. Arpornmaeklong P, Suwatwirote N, Pripatnanot P, et al. Growth and differentiation of mouse osteoblasts and chitosan collagen sponges. Int $J$ Oral Maxillofac Surg. 2007;36(4):328-337.

65. Li X, Wang X, Zhao $\mathrm{T}$, et al. Guided bone regeneration using chitosan-collagen membranes in dog dehiscence-type defect model. J Oral Maxillofac Surg. 2014;72(2):304.

66. Cho BC, Chung HY, Lee DG, et al. The effect of chitosan bead encapsulating calcium sulfate as an injectable bone substitute on consolidation in the mandibular distraction osteogenesis of a dog model. J Oral Maillofac Surg. 2005;63(12):1753-1764.

67. Zhang Y, Song J, Shi B, et al. Combination of scaffold ad adenovirus vectors expressing bone morphogenetic protein-7 for alveolar bone regeneration at dental implants defects. Biomaterials. 2007;28(31):4635-4642.

68. Bahattarai G, Lee YH, Lee MH, et al. Gene delivery of c-myb increases bone formation surrounding oral implants. J Dent Res. 2013;92(9):840845 .

69. Bumgardner JD, Chesnutt BM, Yuan Y, et al. The integration of chitosan-coated titanium in bone: an in vivo study in rabbits. Implat Dent. 2007;16(1):66-79.

70. Kale TP, Singh AK, Kotrashetti SM, et al. Effectiveness of HemCon dental dressing versus conventional method of hemostasis in 40 patients on oral antiplatelet drugs. Sultan Qaboos Univ Med J. 2012;12(3):330-335.

71. Azargoon H, Williams BJ, Solomon ES, et al. Assessment of hemostatic efficacy and osseous wound healing using HemCon detal dressing. J Endod. 2011;37(6):807-811.

72. Miranda SC, Silva GA, Hell RC, et al. Three-dimensional culture of rat BMMSCs in a porous chitosan-gelatin scaffold: A promising association for bone tissue engineering in oral reconstruction. Arch Oral Biol. 2011;56(1):1-15.

73. Bojar W, Kucharska M, Bubak G, et al. Formation and preclinical evaluation of a new alloplastic injection bone substitute material. Acta Bioeng Biomech. 2012;14(1):39-44.

74. Bojar W, Kucharska M, Bubak G, et al. Bone regeneration potential of the new chitosan-based alloplastic biomaterial. J Biomater Appl. 2014;28(7):1060-1068. 
75. Wu Y, Gong Z, Li J, et al. The pilot study of fibrin with temporomandibular joint derived synovial stem cells in repairing TMJ disc perforation. Biomed Res Int. 2014;2014:454021.

76. Lee YM, Park YJ, Lee SJ, et al. The bone regenerative effect of platelet-derived growth factor-BB delivered with a chitosan/tricalcium phosphate sponge carrier. J Periodontol. 2000;71(3):418-424.

77. Mota J, Yu N, Caridade SG, et al. Chitosan/bioactive glass nanoparticle composite membranes for periodontal regeneration. Acta Biomater. 2012;8(11):4173-4180.

78. Ozmeric N, Ozcan G, Haytac CM, et al. Chitosan film enriched with an antioxidant agent, taurine, in fenestration defects. J Biomed Mater Res. 2000;51(3):500-503.

79. Fakhry A, Schneider GB, Zaharias R, et al. Chitosan supports the initial attachment and spreading of osteoblasts preferentially over fibroblasts. Biomaterials. 2004;25(11):2075-2079.

80. Pang EK, Paik JW, Kim SK, et al. Effects of chitosan on human periodontal ligament fibroblasts in vitro and on bone formation in rat calvarial defects. J Periodontol. 2005;76(9):1526-1533.

81. Bae K, Jun EJ, Lee SM, et al. Effect of water-soluble reduced chitosan on Streptococcus mutans, plaque regrowth and biofilm vitality. Clin Oral Invest. 2006;10(2):102-107.

82. Akncbay H, Senel S, Ay ZY. Application of chitosan gel in the treatment of chronic periodontitis. J Biomed Mater Res B Appl Biomater. 2007;80(2):290-296

83. Akman AC, Tigli RS, Gumusderelioglu M, et al. bFGF-loaded HA-chitosan: a promising scaffold for periodontal tissue engineering. $J$ Biomed Mater Res A. 2010;92(3):953-962.

84. Akman AC, Tigli RS, Gumusderelioglu M, et al. Bone morphogenetic characteristics of MC3T3-E1 cells. Artif Organs. 2010;34(1):65-74.
85. Liao F, Chen Y, Li Z, et al. A novel bioactive three-dimensional beta-tricalcium phosphate/chitosan scaffold for periodontal tissue engineering. $J$ Mater Sci Mater Med. 2010;21(2):489-496.

86. Ge S, Zhao N, Wang L, et al. Bone repair by periodontal ligament stem cell seeded nanohydroxyapatite-chitosan scaffold. Int $J$ Nanomed. 2012; 7:5405-5414

87. Nagahara A, Mitani A, Fukuda M, et al. Antimicrobial photodynamic therapy using a diode laser with a potential new photosensitizer, indocyanine green-loaded nanospheres, may be effective for the clearance of Porphyromonas gingivalis. J Periodontal Res. 2013;48(5):591-599.

88. Yan XZ, Nijhuis AW, van den Beucken JJ, et al. Enzymatic control of chitosan gelation for delivery of periodontal ligament cells. Macromol Biosci. 2014;14(7):1004-1014.

89. Petri DF, Donega J, Benassi AM, et al. Preliminary study o chitosan modified glass ionomer restoratives. Dent Mater. 2007;23(8):1004-1010.

90. Travan A, Marsich E, Donati I, et al. Silver-polysaccharide nanocomposit antimicrobial coatings for methacrylic thermosets. Acta Biomater. 2011;7(1):337-346.

91. Elsaka SE. Antibacterial activity and adhesive properties of a chitosan-containing dental adhesive. Quitessence Int. 2012;43(7):603-613.

92. Saker S, Alnazzawi A, Ozcan M. Adhesive strength of self-adhesive resins to lithium disilicate ceramic ad dentin: effect of dentin chelating agents. Odontology. 2016;104(1):53-59.

93. Uysal T, Akkurt MD, Amasyali M, et al. Does a chitosan-containing dentifrice prevent demineralization around orthodontic brackets? Angle Orthod. 2011;81(2):319-325. 